\title{
A method for assessing the quality of model-based estimates of ground tenperature and atmospheric moisture using satellite data
}

Man Li C. Wu and Sicgfricd Schubert

Data Assimilation Office, Goddard Laboratory for Atmospheres, NASA GSFC, Grectitelt, Maryland

Ching I. Lin and Ivanka Štajncr

General Sciences Corporation, NASA Goddard Space Fight Cenler, Greenbell, Maryland

Abstract. A method is developed for validating model-based estimales of almospleric moisture and ground temperature using satcllite data. The approach relatcs crrors in cstimates of clear-sky longwave fluxes at the top of the Earth-atmospliere system to crrors in geophysical parameters. The fluxes include clcar-sky oulgoing longwave radiation (CLR) and radiative flux in the window region between 8 and $12 \mu \mathrm{m}$ (RadWn). The approach capitalizes on the availability of satellite estimates of Cl,R and RadWn and other auxiliary satellite data, and multiple global four-dimensional data assimilation (4-DDA) products. The basic methodology employs off-line forward radiative transfer calculations to gencrate syuthetic clear-sky longwave fuxes from two different 4-DDA data sets. Simple lincar regression is used to relate the clear-sky longwave fux discrepancies to discrepancies in ground temperature $\left(\delta T_{y g}\right)$ and broad-layer integrated atmospheric precipitable water $(\delta p w)$. The slopes of the regression lines deline sensitivity parameters which can be exploited to help interpret mismalehes between satcllite obscrvations and model-based estimates of clear-sky longwave fuxes. For illustrition we analyze the discrepancies in the clear-sky longwave fluxes betwecn an carly implementation of the Goddard Earth Observing Systcm Data Assimilation System (GEOS2) and a recent operational version of the European Cente for Medium-Range Weather Forcasts data assimilation system. The analysis of the synthetic cleal-sky nux data shows that simple linear regression cmploying $\delta \%$, and broad hayer $\delta p w$ provides a good approximation to the full radiative transfer calculations, lypically explaining more than $90 \%$ of the 6 hourly variance in the flux differences. These simple regression relations can be inverted to "retrieve" the errors in the geophysical parameters. Uncertaintics (normalized by standard deviation) in the monthly mean retricved parameters range from $7 \%$ for $\delta T_{g}$ to $\sim 20 \%$ for the lower troposplieric moisture betwecn $500 \mathrm{hPa}$ and surface. The regression relationships developed from the synthelic flux data, together with CLR and RadWn observed with the Clouds and Earth Radiant Encrgy System instrument, are used to assess the quality of the GEOS2 $T_{g}$ and $\mathrm{pw}$. Results showed that the GEOS $2 T_{\theta}$ is too cold over land, and $p w$ in ujper layers is too high over the tropical oceans and too low in the lower atmospliere.

\section{Introduction}

While much progress has becn made to improve the climate characteristics of general circulation nodels (GCMs), the hyJrological cycle stands out as a major component of the EarthAtmosphere system which is still poorly modeled |c.g., Gates at al. 1999; Lan et al., 1995]. Major advances in modeling the hydrological cycle are lampered by inadequate and/or incomplete measurements of sucl quantitics as precipitation, litcm heating, clouds, atmospheric and soil moisture, and ground temperature. Data obtained by methods of four-dimensional data assinilation (4-DDA) suffer from errors in these quantitics, both as a result of errors in the assimilating models and a lack of olsservations to directly constrain the hydrological cycte.

This paper is wot subject to U.S. copyright. Published in 2000 by the American Geophysical Union.

Paper number 2000JD'00478.
In this study we focus on methods to verify model-based (including 4-DDA) moisture profiles $(q)$ and ground temperalure $\left(T_{y}\right)$ using satellite data. We focus on these two paramelers hecaluse they are highly dependent on the parameterizalius of sub-grid-scale processes, and they are difficult to validate because there are few reliable olsservaltions df these quantities with global covernge. The quality of the ground temperature directly reflects on the quality of the land surface formulation, while the moisture profiles are importa it constraints on the behavior of the boundary layer and corvection schemes. The methodology described here was develuped as the result of efforts to validate these quantities in a glol al datat assinilation systcm, but the methodology should als. prove uscful for atssessing systematic crors of global atme ipheric nodels.

The basic methodology is as follows: First, sensitivity parametcrs arc obtaincd by applying off-linc forward radiativ : trans- 
fer calculations to two different assimilated data products to relate differences in clear-sky longivave fluxes at the top of the Earth-atmosphere system to errors in geophysical parameters. The clear-sky longwave fluxes include clcar-sky outgoing longwave racliation (CLR) and radiative llux in the window region between 8 and $12 \mu \mathrm{m}$ (RadWn). The assimilated data sets should provide physieally reatsonahic and global estimates of the geophysical ficlds. Any discrepancics in the ficlds from the (wo different systems measure our uncertainty and provide a tool for assessing the sensitivily of the CLR to discrepancies in these fields. The sensitivity parameters together with satellite cstimates of clear-sky longwave fluxcs (and other auxiliary satcllite datal) are then used to relate the clear-sky longwave fluxes to errors in the geoplysical fickds. For purpose of illustration, sensitivity paranelers are obtained by comparing ground temperatture and atmospheric temperature and moislure protiles from an early implementation of version 2 of the Goddard Earth Observing System (GEOS2) data assimilation system [Data Assimilation Office (D^O), 1996] with those quantitics from a recent operational version of the European Centre for Mediun-Range Wealher Forecasts (ECMWF) dala assinilation system [Courticr et al., 1998].

The key satellite data used for this study are the CLR and RadWn estimates from the Clouds and Earth Radiant Energy System (CERES) [Wiclicki el al, 1996] instrument onboard the Tropical Rainfall Mcasurement Mission (TRMM).

This approach to validation is viewed as a compromise between a simple comparison of model-generaled and olsserved CLR and RadWn and full retricval algerrithms that attempt to exploit information in multiple spectral hands to dhtain estimattes of the geoplyysical quantities. The method provides insight into the nature of the errors in the model-batsed CLR and RadWn consistent with the broadband nature of the CLR and RadWn sattellite measurcmenls.

Sections 2 describes the sittellite data and radiative tratusfer model used for the forwarel calculation. The methodolegy is described in section 3. The sensitivity amalysis, based on the GEOS2 and ECMWF assimilated datn, is described in section 4. A comparison with the CERES/TRMM clear CLR and RadWn is presented in scetion 5. Discussion and conclusions are given in section 6 .

\section{Satellite Data and Radialive Transfer Model}

The primary quantity anilyzed in this study is the CIR and RadWn. The availability of high-çuality satellite estimates of CLR and RadWn (sec below) has made these inportant gutultitics for validating global models. Relating and understanding differences between model-computed and observed CLR and RadWn is complicated by a number of factors. Some of the differences arise from sampling differences and fundamental differences betwecn satellite measurements and nodel "gridscale" ficlds. In this study we focus on the problem of relating the crrors (computed minus observed) in CLR and RadW 11 lo deficiencies in the model-based estimates of the radiatively important geophysical guantitics (c.g., atmospheric moisture and temperature and ground (emperature). The methodology is Jeveloped with synthetic flux data to circumvent the sampling and representativeness problems. These issues are beyond the scope of this initial study, though they will need to be addressed when developing quantitative cstimales of errors in the geophysical quantitics based on safellitc mensurements. We note that in this study the model-based CLR and RadW/ are computed in an ofl-linc mode (sec below). Many institutions new routincly compule Cl.R on-line during the ceurse of molel integrations.

In the following we clescribe the CLR and RadWis data, various other auxiliary diata sets used for this study, i nd the radiative transfer schence used for the off-line calcultion of CLR and RatdWn.

\subsection{ClR and RadW'n Satellite Data}

While the selsitivily paramelers will be develeped w th synlhetic flux data (sce next section), our application of thr: methodology to validating GISOS2 (see section S) will requ ire satcllite observations as input. For the lalter we hate o hained Cl:RLS/TRMM datat [Wielicki et al, 1996). The qualit of the CriRES data is comparable to the quality of the Earth Radiation Budget Experiment (I:RIBГE) data for instanlaneous radiance, lluxes, and secole iype. Generally, radliance uns ertainties are at the [\% level or less. Some differences tetween CIERES/TRMM and ERBIE-TERBS are as follows: the ficld of view resolution, the spectral response of the instrumer ts, and the tropical only eoverage of TRMM [Wiclicki al al., 1 296].

\subsection{Radialive Transfer Schenne}

For the sessitivily calculations we employ the radiative transfer scheme developed by Chon and Sinarcz [199ti]. This scheme is used in the GEOS2 nodel. The longwave (LW) calculation hats niue batuds (band 10 is added to compute flux reduction due to $\mathrm{N}_{2} \mathrm{O}$ in the $15 \mu \mathrm{m}$ region). The tratss nission and aborption of $\mathrm{I}, \mathrm{O}, \mathrm{I}_{2} \mathrm{O}$ continum, $\mathrm{CO}_{3}, \mathrm{O}_{3}, \mathrm{CK}, \mathrm{CH}_{11}$ and $\mathrm{N}_{2} \mathrm{O}$ is modeled using $k$ distribution. In the LW, nultipliciltion approximation for bands are assumed. The LW scheme compares well with detailed line-by-line calculations. The root mean square (rnis) crrors of CLR are betwecin 1 and $3 \mathrm{Wm}^{-2}$ [Chou and Kouvaris, 1991; Chou et al., 1995; Kratz ct al., 1998]. In atdition, the code has been participated in the Intereomparison of Ratdiation Corles in Climalle Models (ICr:CCM) [l:llingson at al., 1991].

Surface emissivity depends on surface property or vegetated surface. For a given surlace type, its values are also different for different wavelengths in the LW spectrum. The global distribution of surface type and the associated emissivity that we used were liken from CERES. The Advanecd Spaceborne Thermal Fintission and Reflection Radliometer crealcd an catsily acecssible thata set on the basis of extensive neatsurements of the spectral reflectances of surface material in the $2.16 \mu \mathrm{m}$ region by Satishury and J'Aria [1992]. Willer at al. [15\%9] derived spectrum emissivity from the spectrum reflectance on the hasis of scenc lype. The scene type was determined by using a $1 \mathrm{~km}$ map of the Intcrnational Gcosplere Biusphere Program seene types as supplied by the U.S. Gcological Survey (I JSGS). A scenc type of tundra was added to scparate it from descrt resulting in 18 surface types. We calculate the fraction foch scene lype in a $2^{\circ} \times 2.5^{\circ}$ longitude and latitude box fi mo the $1 / 6^{\circ} \mathrm{c}$ chulal angle diala. Ratliative nuxes are computed in sach of the $2^{\circ} \times 2.5^{\circ}$ boxes scveral times on the basis of the nut aber of scenc types in a box (maximum is 18 ). The final mean ri diative fux is an area mean of the fractional type. Surface enissivity effect on CLR is large over the desert regions, where off-line compulations show it call be as high as $5-8 \mathrm{Wm}^{-2}$ mosily from window batuds).

\subsection{Ozonc}

The anilyzed orone fields from the Goddard Earth ()bserving System (GFOS) ozonc diata assimilation systen (DAS) 
[Riishojgaard et al., 1999; Stajner ct al., 1999] are used in this study. They are obtained by assimilating total column ozonc obscriations from the Total Ozonc Mapping Spectrometer (TOMS) and ozonc profile observations from the solar backscattered ultraviolet/2 (SBUV/2) instruments into an off-line transport model driven by the GEOS-DAS alssimilated winds. While the statistical analysis of ozonc is performed at every nodel time step (15 min) using a global physical space-bascd analysis scheme, the analyzed ozone is written out at the same frequency and resolution as the other GEOS-DAS fields. The high quality of the ozonc ficlds is illustrated by two eximples from their yalidation for January 1998. The avcrage mo difference between TOMS observations and total column ozone forccast is about 11 Dobson units or $3.7 \%$ of the average total column ozonc. The comparison of analyzed ozone profiles with independent ozone observations measured by the Halogen Occultation Experiment (HALOE) onboard the NASA Upper Atmosphere Research Satcllite shows that the mean profiles agrec within $3.2 \%$ between the pressures of 30 and $1 \mathrm{hPa}$. In this region the HALOE measurcments agrec within $5 \%$ with ozonesonde, lidar, balloon, rocketsonde, and other sitcllites ozone mensurements [Brill cl al., 1996].

While the ozone contribution to CLR is relatively small, the accuracy of its distribution is critical for the CLR computation. In particular, the high ozone concentrations in the stratosplicre and its presence in the water vapor window region are important for the clenr-sky flux.

\section{Methodology}

To help understand the methodulogy, we start with the raJiative transfer cquations for clear-sky conditions in the LW region of the spectrum given

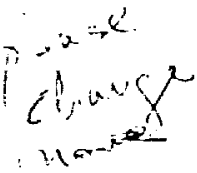

We consider a change in the CLR in terns of the following lincarization:

$$
\begin{aligned}
& \delta \text { CIR }\left(T, q, T_{\eta}\right)=\frac{\lambda \mathrm{CLR}}{i T_{p}} \delta T_{y}+\sum_{i} \frac{i \mathrm{CLR}}{\partial q_{i}} \delta q_{i} \\
& +\sum_{i} \frac{i \mathrm{Cl}, \mathrm{R}}{i T_{i}} \delta T_{i}
\end{aligned}
$$

where $\delta q_{i}$ and $\delta T_{i}$ are the differences in the tivo moisture and temperature products in layer $i$. We consider the par ial derivatives in (2) as sensitivily parameters relating change; in the geoplysical quantitics to changes in the CLR. The validity of this approximation will be examined in the following sce tion by comparing results from the full radiative transfer calculations (referred to as the "Irue" values in the following disct ssions) with results from "kest lit" lincatr regression cquation: based on (2).

\section{Sensitivily Analysis}

In this section we slanl compute the sensitivity paramelers defined previously using output from two different 4-DDA systems (GEOS2 and ECMWF). Note that since we are only interested in differences, there is no necd in these calculations to assune one or the ollier 4-DDA systems is coriect. In section 5 we will use the scnsitivity parameters together with sattellite data to validate lle GLOS2 system.

GISOS2 represents a major upgrade to the bascline GEOSI system comployed in the NASA first reannlysis effort ISphubert at al., [99.3]. The finil version of crFoS2 includes a pliysicalspace three-dimensional variational analysis algorithm (Physicil-Space Statistical Analysis Systcm (PSAS) [Cohn el aí, 1998]) and numcrous improvements to the gencral circulation model. The model inprovements include a more accurate dynamics [Takacs and Sirarcz, 1996], a gravity wave drag :sclicme [Zhou et al., 1996], improved diagnostic clouds, the mosaic land surface sclicme of Kosster and Suarez [1994], a li vel 2.5 moist turbulence scheme [Helfand at al., 1999], ind n iw SW and L.W radiation code iChon and Suarcz, 1994]. 'The system also includes the capability to assimilate TOVS moist re and Special Sensing Microwave/Imager (SSM/N) total prec pitable water. ( Went: $1 ;$; )

The version of GLOS2 used here was run with 70 rertical layers extending to $0.01 \mathrm{hPa}$ and with a spatial resolutio $\mathrm{n}$ of $2^{\circ}$ $\times 2.5^{\circ}$ latitude-longitude. The $T_{\text {, }}$ output was saved :very 3 hours, while the upper air $T$ and $q$ were saved every $t$ hours. The GEOS2 data arc compared with uperational analys es gencritcel hy lice LCMWVF for Janutary 1998. These datia ar a availalile every 6 hours and have been inlerpolated to a $2^{\circ} \times 2.5^{\circ}$ grid to be consistent with the GEOS2 data.

As described in the previous section, $T_{g}, T$, and $q$ fren both analyses are input to a radiative transfer model to comr. ute the CLR and Rad $W_{n}$. The prinary interest for this study $i:$ in the sernsitivity to $T_{g}$ and $q$. Our initial analysis showed that 7 differences belween (il:OS2 and BCMWl are small, and the effect on the computation or CLR is around $\pm 1.5 \mathrm{Wm}^{-2}$.

In the following, Cl.R computed by using all GEOS2 dita is refered to as CLRGEOS2, and the CLR computed using all ECMWF dattit is referred to as CLRECMWF. Sensitivities are estinaled by recompuling the CLR after replacing selected input ficlds. For example, to estimate $\partial C L R / \lambda T_{y}$, we compute the CLRGEOS2 as hefore but replacing the GEOS2 $\gamma_{p}$ with sensitive to the CLR and how the sensitivity varics over the globc.

where $\nu$ is frequency, $B_{n}$ is the Planck parameter, $\varepsilon_{*}$ is surface

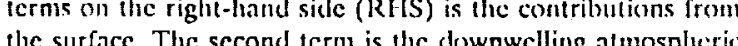
mall compared to the other tcrms. The third term is the

The first step is to develop sensitivily paramelers relating CLR differenees to differences in the geophysical quimtities. This is carried out here using data from two different four dinensional data assimilation systems. The simulated radiances are computed using the $T_{p}$, and $q$ and temperature $(T)$ profiles as input to the radiative iransfer calculations using the scheme described in the previous section. The tim of this step is to try to understand which aspect of the input data is most

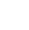
. 
Whe $T_{\text {g }}$ from the ECMWF data. We will refer to this as CLRGEOS2 $\left(\delta T_{g}\right)$, indicating the calculation is carricd out with the GEOS2 ground icmperature perturbed by the anount $\delta T_{g}=T_{n}$ (ECMWF) $-T_{g}$ (GEOS2). The difference $\delta \operatorname{CLR}\left(\delta T_{y}\right)=\operatorname{CLRGEOS} 2\left(\delta T_{y}\right)-\operatorname{CLRGEOS} 2$ which divided by $\delta T_{g}$ is a measure of the scnsitivity of CLR to ground Iemperature. For cxample, the change in CLR duc in differences in $T_{g}$ is then denoted by $\delta C L R\left(\delta T_{g}\right)$. An estimale of the sensitivity of CLR to $T_{g}$ changes is

$$
\frac{\partial \mathrm{CLR}}{\partial T_{g}} \approx \frac{\delta \mathrm{CLR}\left(\delta T_{g}\right)}{\delta T_{g}} \text {. }
$$

Since the scnsitivity of CLR to moisture varics with height, sensitivity ratios are estimated scparately for different layers in the atmosphere. For these calculations we used ECMWF data as the basis for determining the moisture sensitivity since we felt that the ECMWF moisture values were more reasonable especially at upper levels. In principle, it should not matter which one is used (GEOS2 or ECMWF), since we are only after the sensitivity. In fact, tests showed similar results using GEOS2, though we felt the analysis using ECMWF provided results that were somewhat casicr to interpret for the inoisture. The layer-integrated moisture is referred to as the precipitable watcr ( $\rho w)$. For cxample, we computc $\delta \operatorname{CLR}\left(\delta p w_{h}\right)=$ CLRECMWF $\left(\delta p w_{h}\right)$ - CLRECMWF. Here $\delta p w_{h_{r}}$ is equal to pw from ECMWF minus $\rho w$ from GEOS2, where $p w_{\text {, is the }}$ moisture in the layer between 200 and $500 \mathrm{hPa}$. Sinilar calculations are cione for moisture between 200 and 700 li?:a $\left(p w_{700}\right)$, betwecn 200 and $900 \mathrm{hPa}\left(p w_{900}\right)$, between $200 \mathrm{hPa}$ and surface $\left(p w_{s / c}\right)$, between 500 and surface $\left(p w_{l}\right)$, and ibe full moisture profile (tpw). The sensitivitics to $p w$ are given by cquations analogous to (3). For cxample,

$$
\frac{\partial \mathrm{CLR}}{\partial p w_{h}} \approx \frac{\delta \mathrm{CLR}\left(\delta p w_{h}\right)}{\delta p w_{h}}
$$

estimates the sensitivity of CLR to the pw between 200 and 500 hPa.

We use the period January 1998 to compute the sensitivity parameicrs, since we have in-house operational analyses from ECMWF for this time period. Unless noted ollerwise, all calculations are based on 6 hourly data on the GEOS $22^{\circ} \times$ $2.5^{\circ}$ grid. We estimate the sensitivitics focally using simple regression to relate the 6 hourly differences in CLR (ur SCLR) to differences $(\delta x)$ in the input quantities. For a single predictor the regression equation takes the form

$$
\delta \operatorname{CLR}(\delta x)=\alpha_{x} \delta x+\varepsilon,
$$

where $x$ is the quantity being varied (for cxamplc, $T_{2,}, w_{11}$, or $\left.p w_{l}\right), \alpha_{x}$ is the sensitivity parameter to be cstimiated, and $e$ is the component of the $\delta C L R$ not explained by $\delta x$.

Before computing the sensitivity parameters, we first examine the differences in the CLR from the two assimilated data sets and look in some detail at the various band contributions to the total CLR. Figure I shows the mean SCLR = CLRGEOS2 - CLRECMWF for January 1998 computed from the 6 hourly data. Over land the differences can be as large as 15-20 $\mathrm{Wm}^{-2}$ and over the oceans as large as 20-25 $\mathrm{Wm}^{-2}$. Figures $\mathrm{lb}$ and $\mathrm{lc}$ show $\operatorname{SCLR}\left(\delta T_{y}\right)$ and $\delta \operatorname{CLR}(\delta q)$, respectively. The pattern and magnitude of the $\delta C L R$ distribution over land is very close to $\delta \operatorname{CLI}\left(\delta T_{p}\right)$, while over

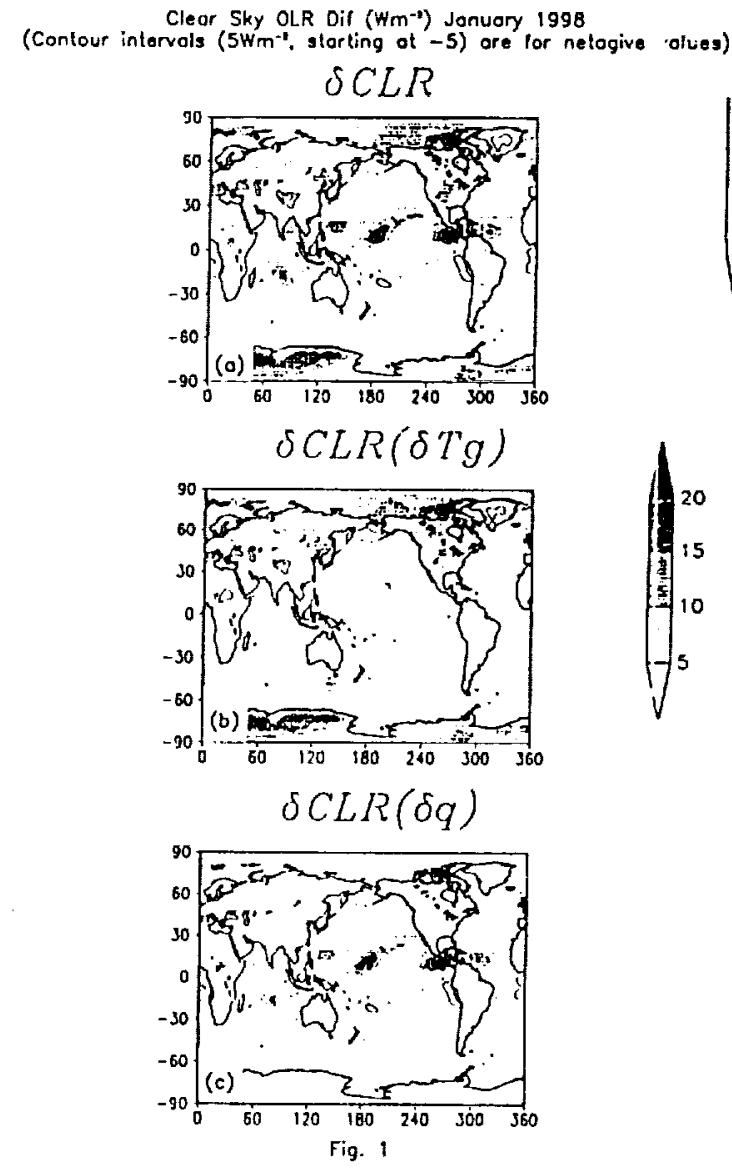

Figure 1. Monthly mean SCLR $\left(\mathrm{Wm}^{-2}\right)$ bised in the GEOS2 data and the lECMWI data: (a) differences ind iced by $\delta T_{q}$, $\delta \%$, and $\delta T_{;}$(b) differences induced by $\delta T_{4} ;$ : nd (c) differences induced by $\delta q$. Contours are for negative values; the intervals are the same as the shaded values.

oceans, $\delta C L R$ is very similar to $\delta C L R(\delta q)$. This indica es that for these two assimilated data sets the largest discrepancies in CLR over the land poleward of about $40^{\circ}$ latitude are due to ground temperature differences, while he largest distrcpancies in CLR over the oceans are due to differences in the moisture profiles.

To better understand the sources of the CLR from the atmosplere and lind, we look in more detail at the various

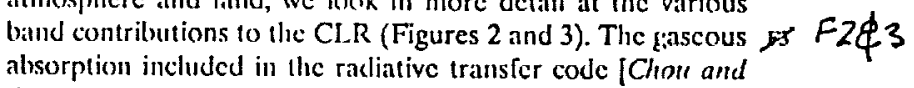
Sunrez, 1994] arc $\mathrm{H}_{2} \mathrm{O}, \mathrm{CO}_{2}, \mathrm{O}_{3}$, and trace gases (sec section 2.2). In the following we will focus on the water vapor effect. Columu I in Figure 2 shows the CLR computed from the IECMWF data in each of the nine bands. The first thee bands are the contributions from the water vapor rotational bands. The next three are the contributions from the 800 to 1215 $\mathrm{cm}^{-1}$ window region, and the last threc represent contribuslions from waler vapor vilbration and rotation bands. Column 2 shows the emission from the surface $\left(\varepsilon_{v}, T_{y}\right)$. Column 3 is the contribution to the (I.R from the first two terms on the RIIS<smiles>CCC</smiles>

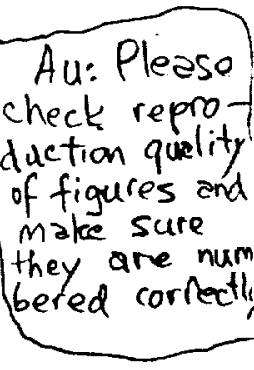
of
make
they aned correctl
bered 
T G I

Docket \#-238068

WU ET AL: ASSESSING GROUNID TEMPERATURE ANI ATMOSPIIERIC MOISTURE

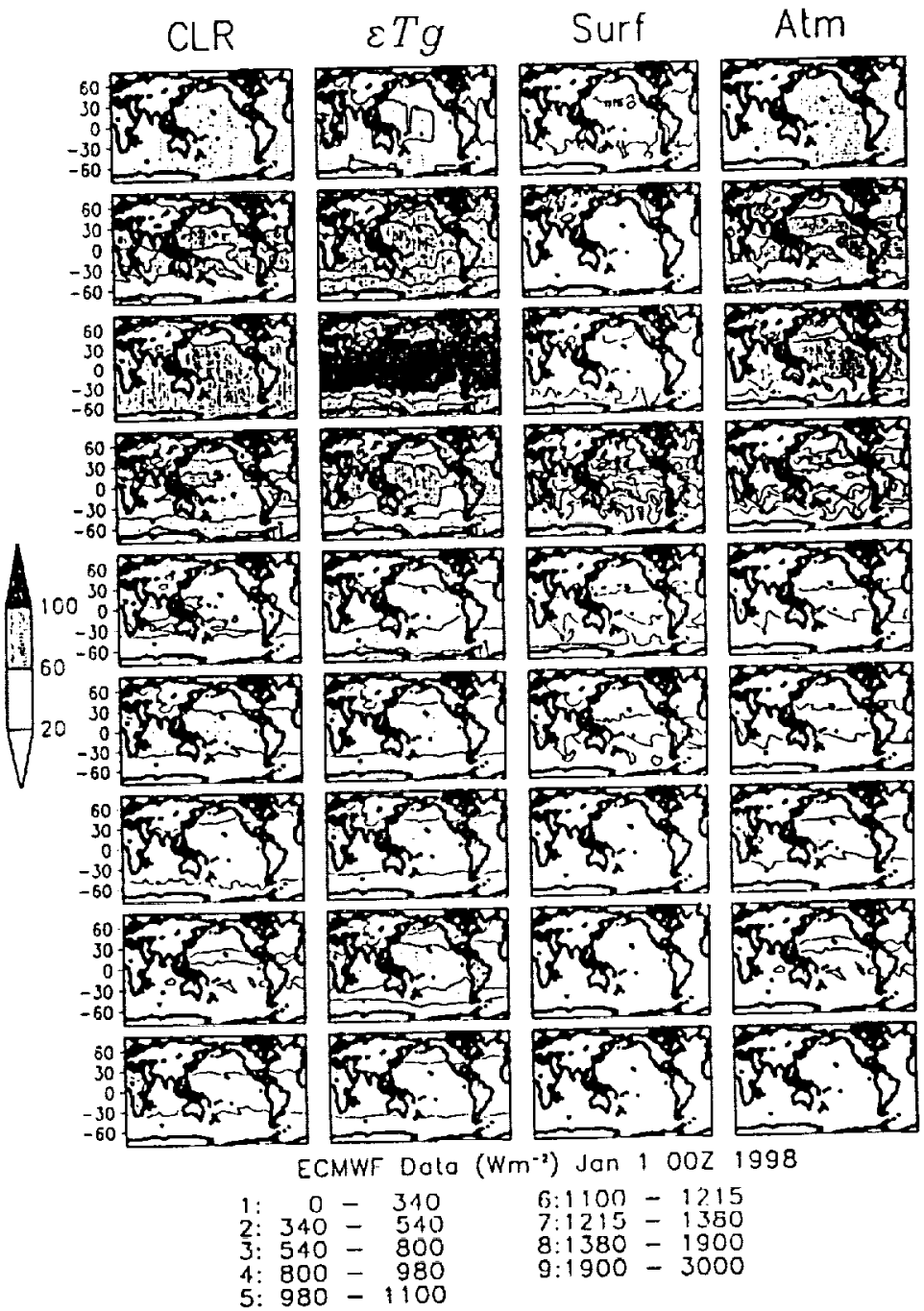

Figure 2. Contributions to $\mathrm{CLR}\left(\mathrm{Wm}^{-2}\right)$ [rom different parts of the atmosphere and different bands. From top down the band ranges from band I to band 9 , the wave number for cach band is shown at the bottom of the figurc. Value $\varepsilon T$ is surface entission, Surf (surface contribution) is the first two terms of the RHS of (1) and Atm (contribution from the atmosphere) is the third term of the RIIS of (1). Contour intervals are 10 $\mathrm{Wm}^{-2}$ except the last one in a column, which is $5 \mathrm{Wm}^{-2}$.

of (1), and column 4 shows the contribution to the CLR from the atmosphere (third term on the RHS of (1)).

The strength of surface cmission follows the Planck function which peaks in the third band $\left(540-800 \mathrm{~cm}^{-1}\right)$. The intensity from the other bands decreases gradually toward both sicles. Note that the band widths are not uniform. The atmospheric transmission function strongly modifics the surface cmission, cspecially in bands with strong gaseous alsorption. The degree of the atmospheric cffect depends on the opacity of the atmosphere. Comparing, in Figure 2, the surface emission wilh the amount reacling the top of the atmosphere, we find a significant grecnhouse effect due to gascous absorption. The greenlouse effect is very strong in the water vapor rotationat batid ranging from zcro to $800 \mathrm{~cm}^{-1}$ (which include the $15 \mu \mathrm{m} \mathrm{CO}$ band) and the vibrational and rotational band ranging from
$1215103000 \mathrm{~cm}^{-1}$. The largest contributions to CLR are from bands 2 to 4 , ranging from 340 to $980 \mathrm{~cm}^{-1}$, and most of the contributions are from the at mosphere because of the opacity of the water vapor rotational bands and $\mathrm{CO}_{2}$ bands. For example, the surfice has the largest cmission in band 3, but the surface contribution to CLR is relatively small due to the opacily of the atmosplicre. In particular, over the iropical ocans tla surfice contribution to the CLR from this yand is about $5 \%$, white the rest is from the atmosphere (sce $\mathrm{Fi}_{i}$; ure 3). Figure 3 inciudes the effective pressure level of the centributions from the atmosphere averaged over the month. This is determined hy finding the peak of the weighting functio $n$ consputed from the mean transmission functions. In bands: and 3 , most contributions over land are from layers close to iurface (lowest 300 hl'it), while most contributions over the ropical 
Docket \#-2:\$8068

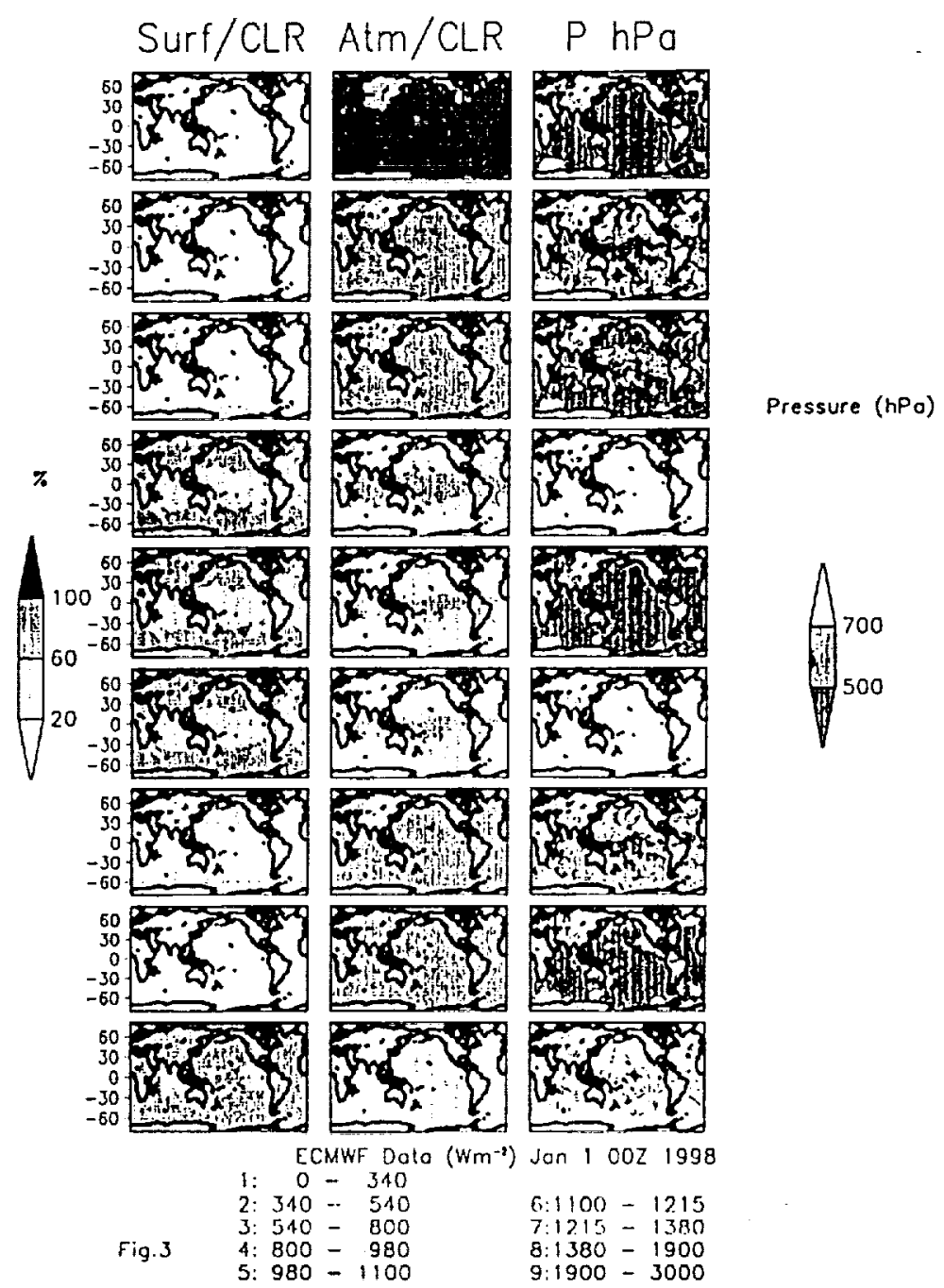

Figure 3. Percentage contributions to CLR (\%) from Surf and $\lambda \mathrm{m}$ and mean peak of the weighting function (hla).

oceans arc from layers ranging from 200 to 500 liPa, where water vapor concentration is high. Away from the tropics the opacity decreases, and the layer of largest emission is lowered to between 500 and $700 \mathrm{hPa}$. In the tropies the almospliere contributes more than the surface in all bands. The litrgest contributions are from between 200 to $500 \mathrm{hPh}$ allu some are from 500 to 700 hPa depencling on the opacity of the atmospliere.

In summary, the major contribution to CLR over the trop)ical occans $\left(30^{\circ} \mathrm{S}\right.$ to $\left.10^{\circ} \mathrm{N}\right)$ is from tlic atmosphere between 200 and $500 \mathrm{hPa}$. In the subtropics the contribution tends to be from lower in the atmosplere between 500 and 700 hiPa. Over land, for the Northern Hemisphere winter, most of the contribution to CLR is from the surface (from window binds) and from the lowest (300 liPa) layer of the atmospliere.

Figure 4 shows the regression results for $T_{g}$ (lind only) for January 1998 based on 6 hourly dalit. We note that sca surface temperature (SST) is specificd from observations in both anlal- yses, and we do not consider any differences in the SS 5 data. The regression is carricd out on the CLR differences resulting from perturlsing only the ground temperature using th tadiallive transfer equation (1). The extent to which the regression explains the results from the full radiative transfer calculation is thus a meisure of the adecpuncy of the linear approxination for the effect of $T_{a}$. The estimated scnsitivily paraneter iC.LIV/it $T_{z \prime} \approx \alpha_{T}$, (Figure $4 a$ ) is highest in the middlc and high latitudes (ranging from 1.2 to $1.6 \mathrm{Wm}^{-2}$ per $1^{\circ} \mathrm{C}$ change in $T_{\text {, }}$ ) and lowest over the tropical land masscs. This is consistcnt with our previous analysis of the various contributions to the CLR (Figure 2) and rellects the latitudinal dependenec of the at. mospherie moisture content. The explained variance is shown in Figure 4b. Remarkably, llic regression line (5) explairs more tham of of of the viriance over most areas (Figure 4b). These results suggest that the sensitivity of CLR to changes in $T_{p}$ can be reasonably cstimated by the simple lincar approximation (5) of the racliative transfer equation. 
Docket \#-2:\$8068
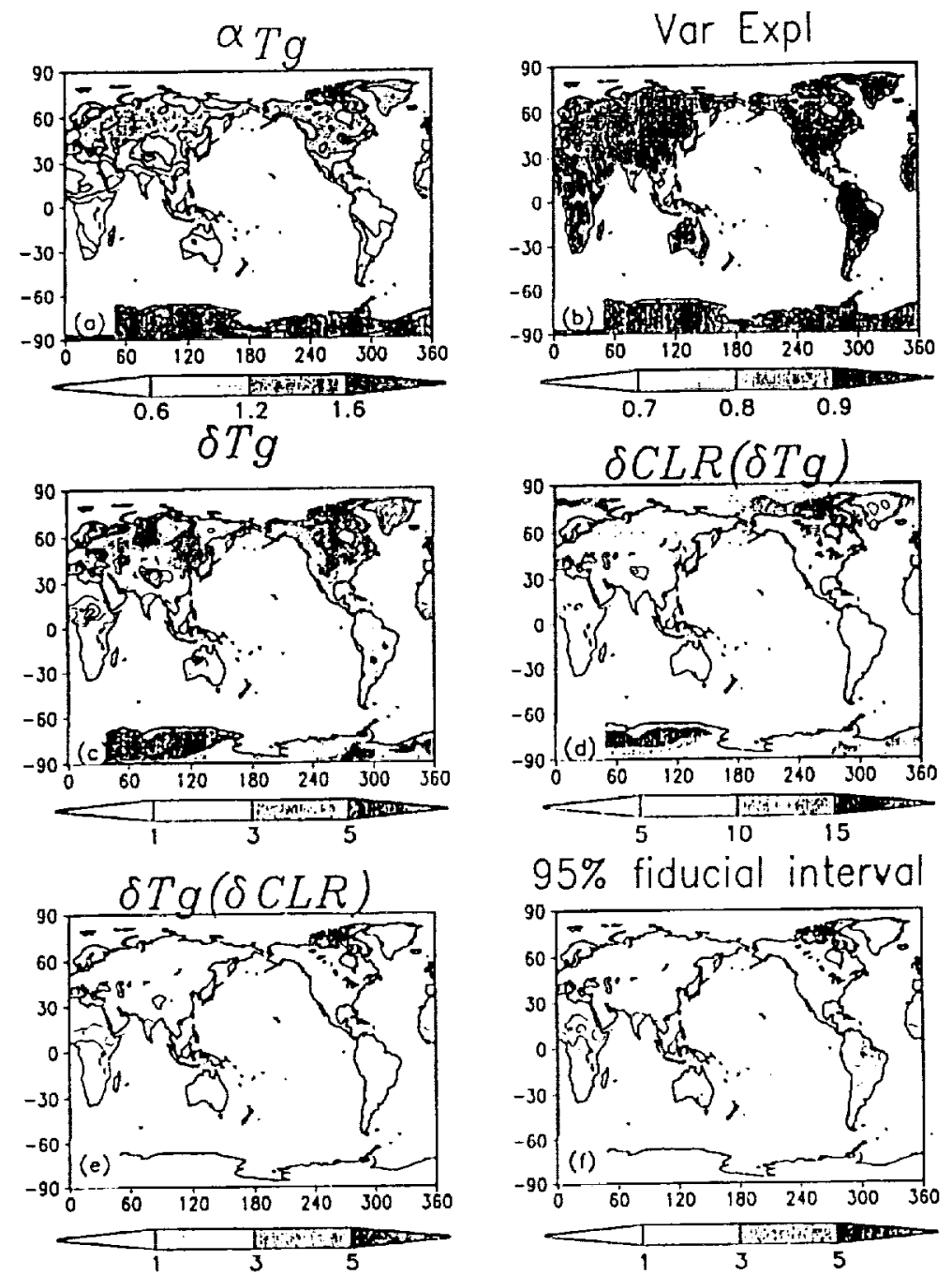

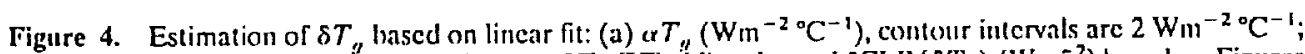
(b) total variance cxplaincd; (c) nonthly mean $\delta T_{q}\left({ }^{\circ} \mathrm{C}\right)$; (d) estimated $\delta \mathrm{CL}, \mathrm{R}\left(\delta T_{q}\right)\left(\mathrm{Wm}^{-2}\right)$ based on Figures $4 a$ and $4 c$; and (c) errors $\left({ }^{\circ} \mathrm{C}\right.$ ) in estimation of $8 T_{g}^{\circ}$ bascd on Figure $4 \mathrm{~d}$ and ( () $95 \%$ fiducial interval. Contours are for negative values in Figures $4 \mathrm{c}-4 \mathrm{f}$; the intervals are the same as the shaded values.

We are interested in the ability of the regression to represent the systematic difference in the CLR fickls. Figure $4 \mathrm{c}$ shows the mean ground temperalure differenee $\delta T_{y}$ between the two data sets for January 1998. The mican temperature differences are quite large over the cold continents accounting for most of the differences in CLR over those regions. Figure $4 \mathrm{~d}$ shows the mean CLR difference from the regression equation evaluated for the time mean $\delta T_{g}$. Comparison with Figure lb shows that the lincar approximation (llie regression line) with just $\delta T_{\text {, }}$ provides a geod approximntion to the time mean differences in CLR over land. The reader is reminded that the results in Figure $\mathrm{lb}$ are computed with the radiative transfer equation and include the effects of $q, T$, and $T_{q}$. We shall see in the next section that the differences in $T_{\text {f }}$ for the most part riffect a cold bias in this version of GEOS2.

We nexl obtain an estimate of $\delta T_{\text {g }}$ by inverting the regression cquation (5): i.c., by solving for $\delta T_{,}$using the cstimatc of cr. For brevily we refer to this estimate of $\delta T_{y}$ as life "retrieved" value. Figure 4o shows the difference between our retrieved $\delta T_{y}$ and the actual valucs shown in Figure dc. The

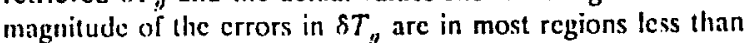
$1^{\circ} \mathrm{C}$. Figure 4l slows that the $95 \%$ fiducial intervals for the inverse regression [ / heuper and Simith, 1981] or retricved values are typicilly $13^{\circ} \mathrm{C}$. Note that here we only show one sides of the two-sided contidence interval corresponding to the sign of the actual error in Figure dc. 

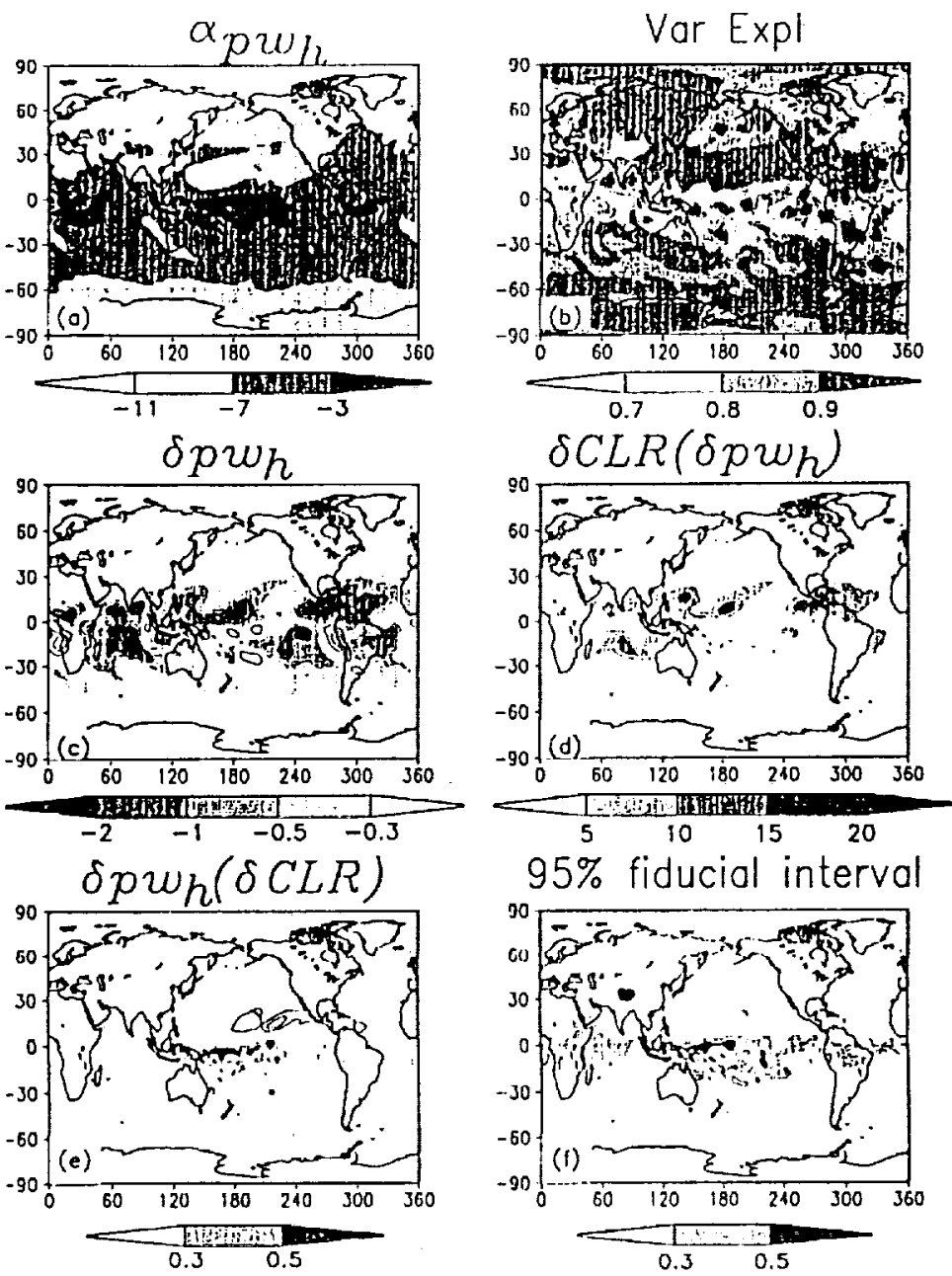

Figure 5. Same as in Figure 4 except for $\delta p w_{n}$ : units atre $\left(W_{m} m^{-2} \mathrm{~mm}^{-1}\right)$. Contour intervals are for values opposite to the shaded values.

Figure 5 is the same as Figure 4 cxcept for the mean moisture difference in the layer between 200 and $500 \mathrm{hPa}\left(\delta p w_{h_{h}}\right)$. Figure 5 a shows the sensitivity parameter $\left(\alpha_{p m_{A}}\right)$ detcrmined from the regression

$$
\delta \operatorname{CLR}\left(\delta p w_{h}\right)=\alpha_{j w_{h}} \delta p w_{h}+\varepsilon .
$$

The spatial pattern of the sensitivity to upper level moisture is largely zonally symmetric, with the lowest sensitivity $(<3$ $\mathrm{Wm}^{-2} / \mathrm{nm}$ precipitable water in the 200-500 hPa layer) in (he convective regions of the tropics, and increasing sensitivity away from the tropics. $A$ region of enhanced sensitivity (>9 $\mathrm{Wm}^{-2} / \mathrm{mm}$ precipitable water in the 200-500 hPa layer) occurs over the subtropical regions of the Nortli Pacific. We note that bands 2, 7, and 8 (Figure 2) show a tendency for cnhanced contributions to the CLR from the subtropies especially over the North Pacific, suggesting the increased sensitivity is coming largely from these bands. Figure 5b shows that the regression line explains more than $90 \%$ of the variance in the CLR over most of the globe. Scattered regions of the tropics and subtropics, the extratropical storm tracks, and the Himala $a s$, explained variance less than 80\%. With those exceptions the lincar approximation io the full radiative transfer calce lations for the impact of the upper level moisture appears to to quite geod. Figure $5 \mathrm{c}$ slows the mean difference in the upp :r level moisture ( $\left.f p w_{n}\right)$. The differences tend to be $n$ :gative (GEOS2 is weller) and largest just outside the tropi s. The results of the regression for the time mean $\delta C L R\left(\delta p w_{1}\right.$ ) (Figure 5 d) again show a good approximation to the full cals ulation (I.igure /c), suggesting that much of the systematic dif crence between GEOS2 and ECMWF CLR over the subtropits are a result of differences in the upper level moisture. The re sults of the inverse calculation (Figure 5e) show that the magnitude of the crrors in the retricvil of $\delta p w$, is in most regions less than $0.5 \mathrm{~mm}$. lïgure 55 displitys the $95 \%$ fiducial intervals on the retricued values. The lypical values range from $0.3106 .5 \mathrm{~mm}$.

Figure 6 is the same as Figure 5 except for the mean mois- F6 
ECMWF and CEOS2 January 1998
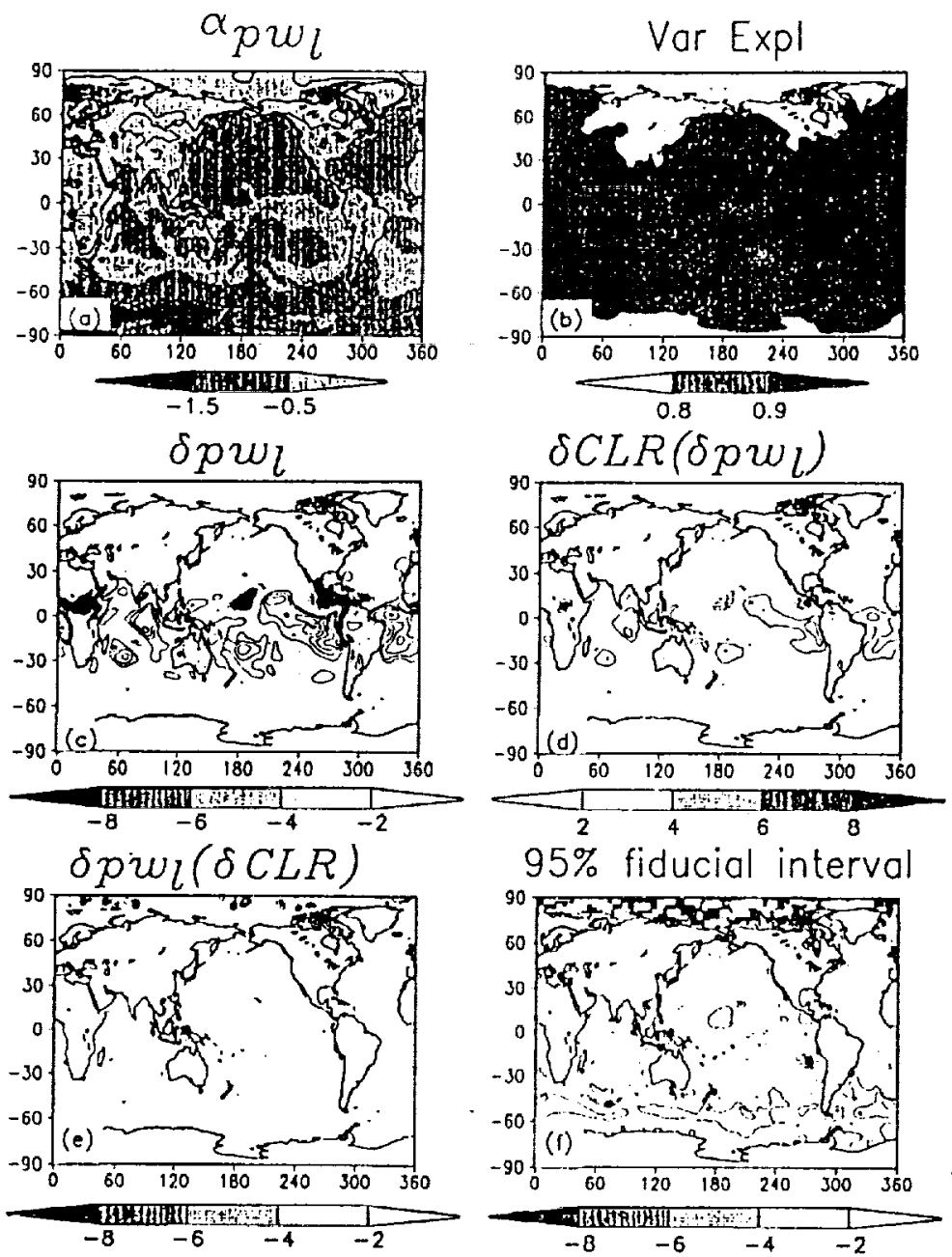

Figure 6. Same as in Figure 4 except for $\delta p w_{j}$ : units are ( $W_{m m^{-2}}$ mom ${ }^{-1}$ ). Contour intervals arc for valucs opposite to the shaded values.

ture difference in the layer between 500 hP'a and the surface $\left(\delta p w_{l}\right)$. Figure ga shows that the sensitivity parameter $\left(\alpha_{p w l}\right)$ is ahout an order of magnitude smaller than the upper level sensitivity parameter $\left(\alpha_{p w_{n}}\right)$. The greatest sensitivity (magnilude $>1$ to $2 \mathrm{Wm}^{-2} / \mathrm{mm}$ precipitable water) occurs at high latitudes in regions that are probably ice covered. Figure fol shows the variance explains by the repression line which explains more than $90 \%$ of the variance in the CLR over most of the subtropics. Generally, less than $80 \%$ of the varianec is explained over the cold continents and the polar regions. Figure $6 \mathrm{c}$ shows the mean difference in the lower-kevel moisture $\left(\delta p w_{1}\right)$. The differences tend to be positive (GEOS2 is drier) throughout much of the tropics and subtropics, with the largest values occurring off the west coasts of Africa and Suuth America in regions characterized by the presence of low-level stratus clouds. There are some regions will negative values in the Northern Hemisphere subtropics that coincide with large neg. ative values at upper levels (compare Figure $5 \mathrm{c}$ ). The results of the regression for the time mean $\delta \operatorname{CLR}\left(\delta p w w_{l}\right)$ is shown in Figure Go. This slows that some of the negative value; along the west coists of Africa, South America, and Africa in the full calculation (Figures la and $1 \mathrm{c}$ ) are due to the differences in the low-level moisture. Figure $6 \mathrm{c}$ shows that the magnitude of the crrors in the retrieval of $5 p w$, is in most regions less than 2 mm. The 45\% fiducial intervals (Figure on are in the: range $\pm 2-4$ mm with the largest uncertainties in the Southern Hemisphere and the north polar region.

We next look nore elosely at the vertical dependence of the sensitivity of CLR to moisture. The pancls on the left-hand side of Figure 7 slow the differences between the ECMWF 87 and the GEOS2 lime mean moisturc. The scnsitivily paraneters are the slopes of the regression lines through the scatterplots of SCLR versus $\delta \mu w$ (pancls on the righte-frand side of [rigure 7). These are computed, in this case, from the monthly mean fields, and cacl point in the scatterplots represents a different grid point (ocean only). This clearly sloows that $\delta C L R$ 
Docket \#-288068

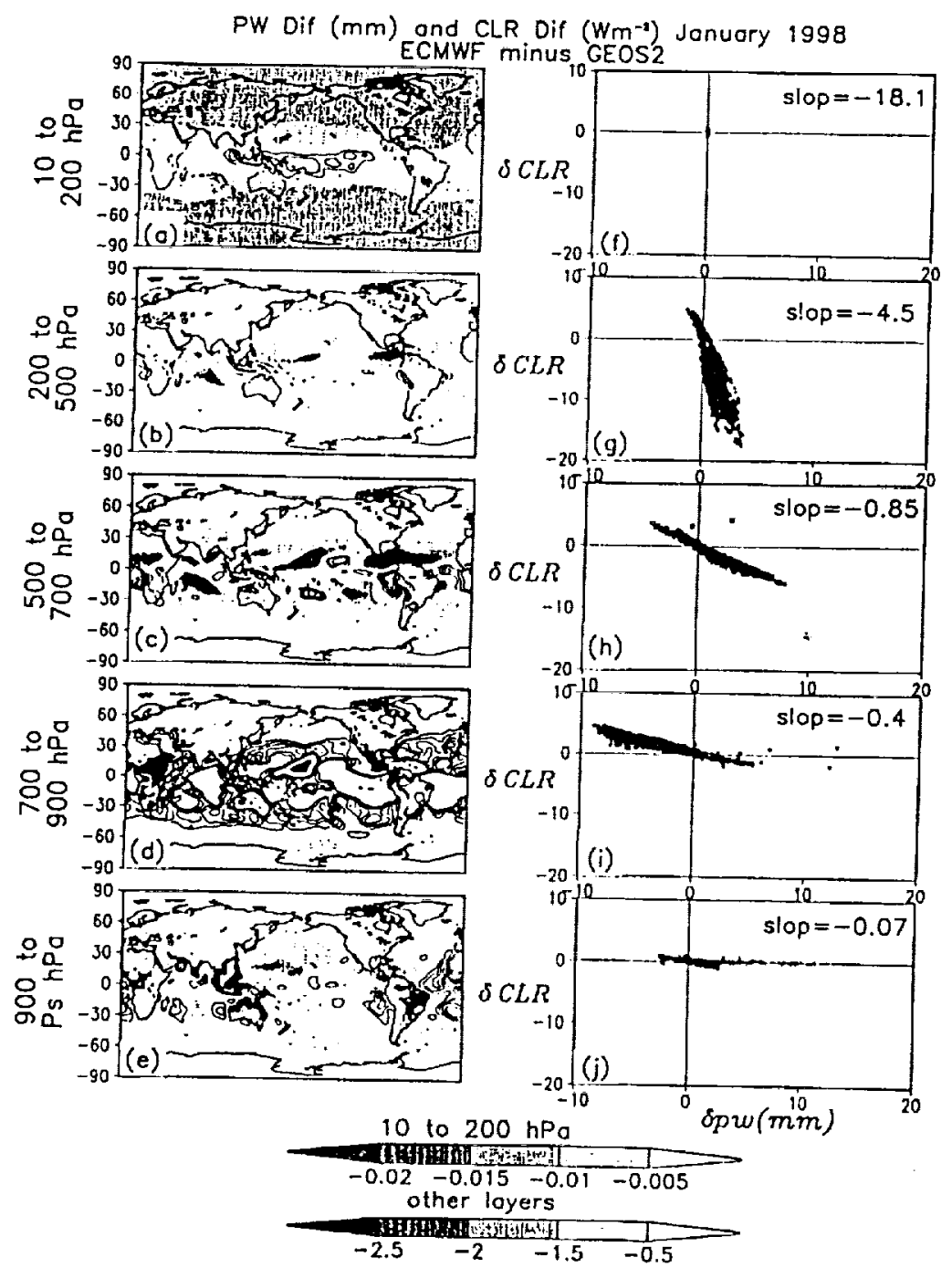

Figure 7. Scusitivity of $\delta C L R\left(\mathrm{Wm}^{-2}\right)$ to $\delta p w(\mathrm{~mm})$. The left-hand side are precipitable water (pw) differences between ECMWF and GEOS2; the right-hand side are scatterplots of SCLR and spw. Contour
intervals are for values opposite to the sladed values.

is most sensitive to $\delta p w$ in the top layers. The sensitivity decreases the fartleer the layer is from the top of the atmosphere. Thus the moisture in the layer close to the surface tends to lave little effect on CLR, consistent with our previous analysis of the contributions to the total CLR (Figure 2). Also, above 200 hPa the amount of moisture is ton small to have an apprisinte impact on the CLR despite the strung sensitivity. This is illustrated in Figure 8, which shows the relative contrihutions by layer to the time mean difference in the CLR Jue to moisture differences. Between 50 and $90 \%$ of the major CLR differences are due to $p w$ differences between 200 and $5000 \mathrm{~h} \mathrm{P}^{\mathrm{B}} \mathrm{a}$ and another 10-30\% comes from the layer between 500 and $700 \mathrm{hPa}$.

We next extend the results of the previous analysis to cont. sider the case where, in addition to the total CLR measurements, we also have availabic CLR measurenents for the wit- dow region. Figure 9 shows line sensitivity para neters ro computed separately for the window region (RadW $n$, te t-hand side pancls) and for the tolal CLR minus RadWn (right-hand sidle pancls). The latter consists of the rotation and vi'mration and rotation (RVR) bands or nonwindow baunds; sec dis :ussion of Figure 21. A comparison of Figures $0_{3}$ and 0 d shoms hat th: $T_{g}$ sensitivity in the window region tends to peak in midelle latiludes, while in the monvindow or RVR, the sensitivity shows a gencral increase with lattude. As such, the preatest sensitivity to $T_{\text {g }}$ over the United States, Europe, and parts of China occurs in the wimlow region. $\Lambda$ comparison of Tigures gh and 92 with ligure sa shows that the $p w_{1}$ sensi ivity is dominated by the RVR bands or nonwindow bands. Over the Iropical oceins the sensitivity to the low-level moislure is greatest in the window region (compare Figures $9 c$ and of). The large sensitivity over the castern North Pacific and Atlan- 
Docket \#-2:18068
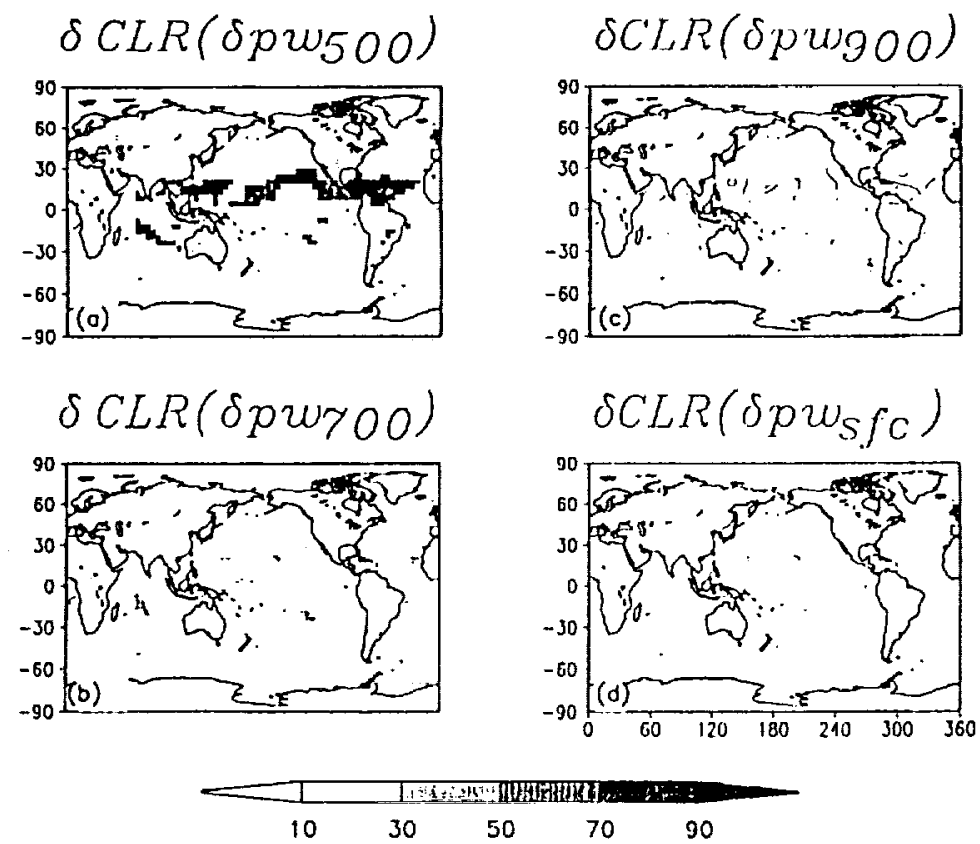

Figure 8. Relative contribution (\%) of layer spuv to SCLR. Conlour intervals are for values opposite to the shaded valucs.

tic seen in the fotal CLR calculation (Figure (ai) is date to the nonwindow bands or RVR bands (lïgure 90 ).

By considering the lincarization (2) for both the RadWn and the RVR bands, we obtain two equations relating the CLR differences in each band to changes in the geoplysical paramcters. If we further limit the approximation of the CLR change to be primarily the result of just two geophysical paraneters, we can estimate or "retrieve" these parameters. The previous results suggest that over land the CLR differences can be approximated by

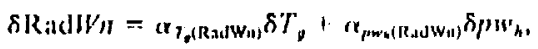

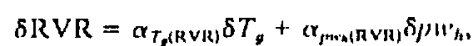

while over occan, the approxination is

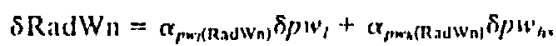

$$
\begin{aligned}
& \delta R V R=\alpha_{p m(R Y R)} \delta p w_{l}+a_{\operatorname{mox}(R V R)} \delta / p w_{h} .
\end{aligned}
$$

Note that in the above relationships the sensitivity parameters (the $\alpha_{x}$ in Figure 9) arc obtained from the 6 hourly data accorcling to (5). By inverting (7)-(\$) and (9)-(10), we oblain the retrieved estimiltes of the differences in the geof hysical parameters assuming the $a_{x}$ and $\delta R a d W_{n}$ and $\delta R V R$ arc known. For example, tle retrieved monthly mean differences in the geophysical parameters $\left(T_{g}, p w_{h}\right.$, and $\left.p w_{l}\right)$ are shown in Figure 10 (left pancls). The actual differences in $T_{y, .0}, w_{1,}$, Flo and $p w$, from the full radiative trans/er equation shown carlier are presented agatin in the right-hand pancls to faciliate the comparison with the estimated values. The global mean bias in the retrieved $8 T^{\circ}$ is $-0.04^{\circ} \mathrm{C}$. The global mean rometmeanscpuare error is $1.77^{\circ} \mathrm{C}$, which corresponds to about $7 \%$ of the standard deviatien of the true values. The global mean bias in the retrieval of $\delta p 1{ }^{\prime \prime}$, is $-0.1 \mathrm{~mm}$. The rms crror is $0.26 \mathrm{~mm}$, which corresponds to about $8 \%$ of the standard deviation of the truc values. Similarly, the global mean bias in the retricval of $\delta p w$ is $0.4 \mathrm{~mm}$. The rms crror is $2.15 \mathrm{~mm}$, which corrcsponils to atrout $20 \%$ of the standard deviation of the true values.

The above results show that (7) through (10) give a close approximation to the mean differences in the ground temper- 
Docket \#-2138068
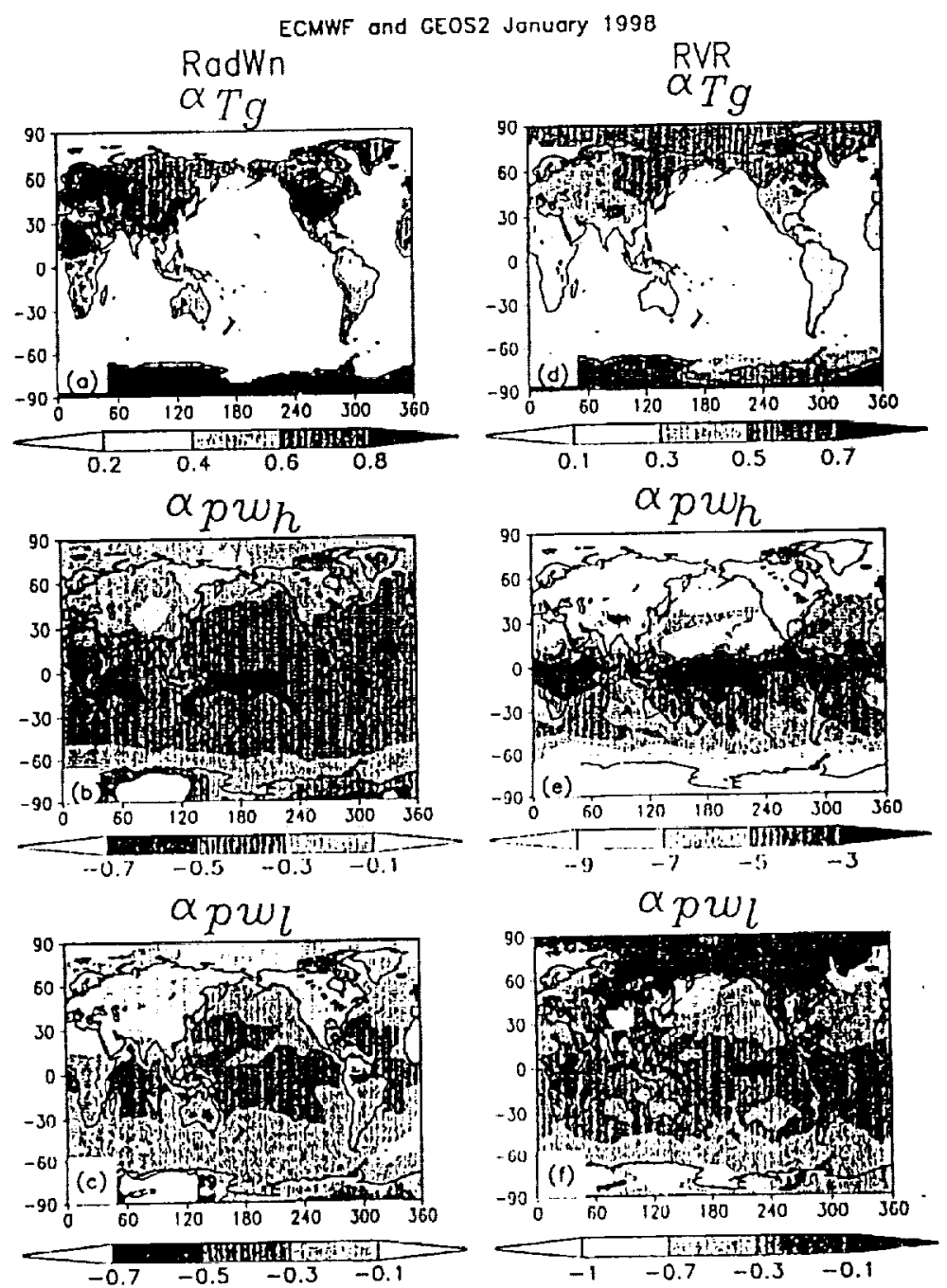

Figure 9. Coefficients of linear fit from Figures $9 \mathrm{a}$ lo $9 \mathrm{c}$ are hased on 8 RadWu and from Figures 9d io 98 Fure

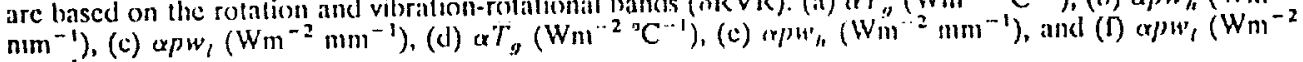
$\left.\mathrm{mm}^{-1}\right)$.

ature and moisturc and suggest that these relationships can be used to infer crrors in the geophysical parameters. In the following section we examine the differences between the synthetic GEOS2 CLR and the CLR from a prelininary CIERES/ TRMM data set.

\section{A Comparison With CERES/TRMM CLR and RadWn}

In the previous section we compared synthetic dear-sky nuxes (CLR and RadWn) computed from two 4-DDA data sets to develop some simple but guantitative measures of the sensitivity of clear-sky fluxes to changes in ground temperature and moisture. Insight into the scositivily of the clear-sky fluxes to clanges in these geophysical quantitics was obtained by compuling separately the various band contributions to the clear-sky liuxes. Reasonable approximations to the scusitivity of elcar-sky fluxes to clanges in the geophysical paramelers were obtained with simple lincar relationships using ground cemperature and moisture in two broad layers of the atmosplere (lle upper anel lower troposphere) to predict th ; clearsky fux changes in the RadWn and RVR bands (or non' vindow hands): lhe single predictor relationships (5) and (6) as well as llse livo parameter relationships (7) through (10).

We found that compared with ECMWF, GEOS2 has substantially colder ground tenuperature during January $19^{\prime} / 8$, with differences ratiging from $3^{\circ} \mathrm{C}$ to more than $7^{\circ} \mathrm{C}$ over $h$ gh latitudes. Over these regions the sensitivity of CLR $\| T_{n}$ is befween 1.2 and $1.8 \mathrm{Wm}^{-2}$ per $1^{\circ} \mathrm{C}$, so differences in tl c CLR range from about 5 to $15 \mathrm{Wm}^{-2}$ in these regions, while yarts of 
T G I

I) ocket \#-238068
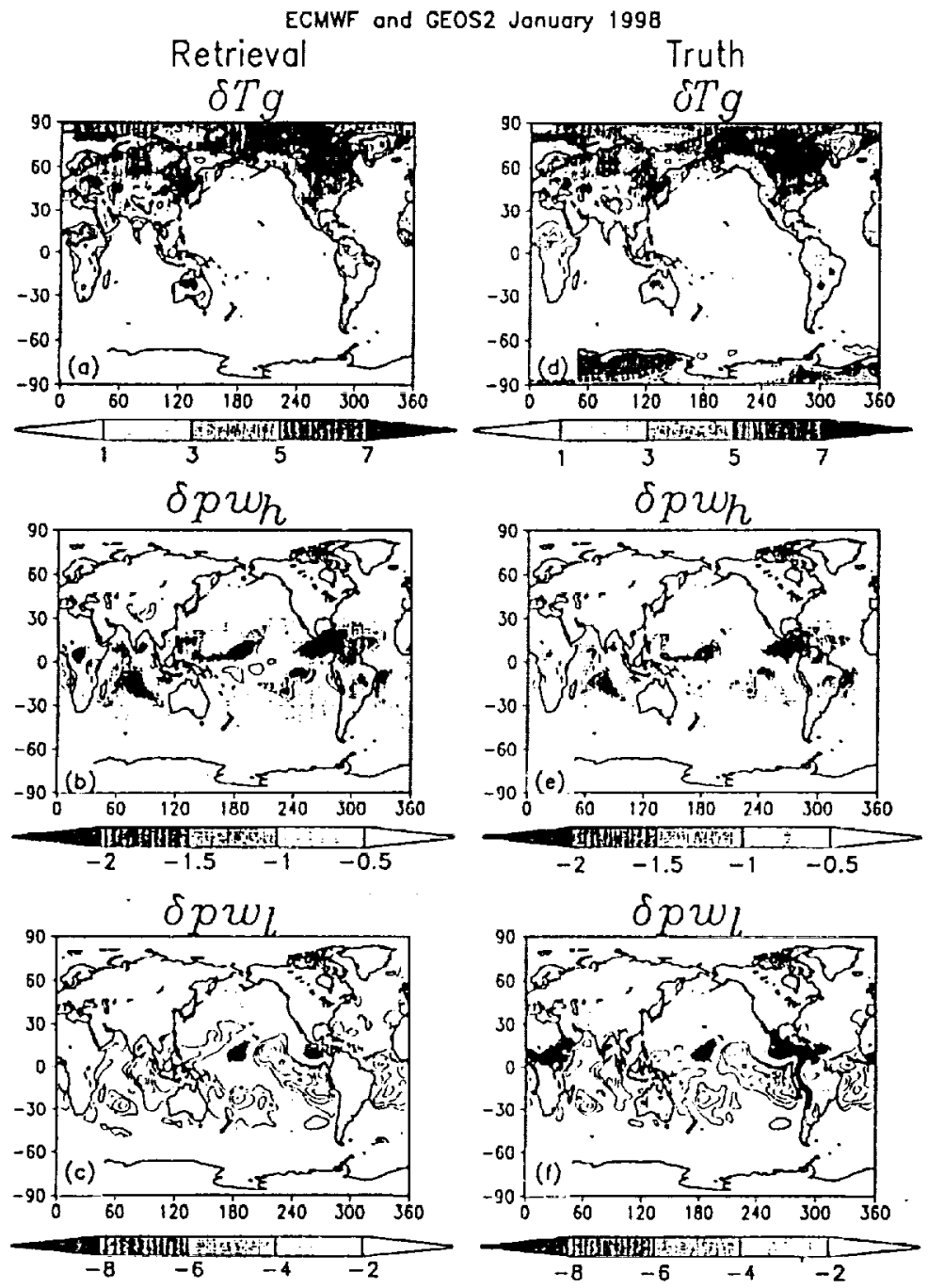

Figure 10. Retricval of (a) $\delta T_{,}\left({ }^{\circ} \mathrm{C}\right)$; contour inlervals are $l^{\circ} \mathrm{C}$; (b) $\delta p w_{4}$ (mu); contour intervals are $1 \mathrm{~mm}$; and (c) $\delta p w_{l}(\mathrm{~mm})$; contour intervals arc $2 \mathrm{~mm}$. True values of (d) $\left.\delta T_{,},{ }^{\circ} \mathrm{C}\right)$; (c) $\delta p w_{4}(\mathrm{~mm})$; and (f) $\delta p w_{1}$ $(\mathrm{mm})$.

the Antarctic show differences exceceling $20 \mathrm{Wm}^{-2}$. Wc also showed (Figures 10c and 100 that compared with ECMWF, GEOS2 is welter in the upper troposplice during January 1998 with differences as large as $2.5 \mathrm{~mm}$ over the tropical ocears. In the lower troposplicere, GEOS2 is drier over most of the tropical occans, with differences as large as $10 \mathrm{~mm}$.

The above results give us confidence in the methodology, though they only provide us with difference (or "crror") ficlds relative to the ECMWF products. We will now use some preliminary CERES/TRMM total CLR and RadW n datil for Jinuary 1998 (in place of the LCMWV analysis datil) to evaluate the quality of the GEOS2 ground temperature over land and moisture over the oceals.

The results for the moisture are shown in Figure 11. We will validate our results against the SSM/I total precipitalble water (TPW). For purposes of illustration and to Jemonsirate the reliability of our algoritlim, we first apply our methodology to the symthetic SCl.R and SRadWn data. Here we assul te that the ECMWF data are the ground truth. The results Figure 11c) show that indeed, we have adjusted the GEOS2 TP w field to le close to that of ESCMWF.

We next demonstrate our algorithm by applying it to the satellite data (CLR and RadWn) and assume that the : atcllite datn are the ground trutl. Figures 1/d-11f show the results of applying our algorithm using the January 1998 CERES obscrvalions of $S C L R$ and $\delta R$ ildWn. Figure $11 d$ indicates tiat our noisture between 200 and 500 hPa is excessive over the tropical regions. Figure IIe indicates that at low levels GE:OS2 is too dry in subtropical regions around $\pm 20^{\circ}-30^{\circ}$ in both henispleces. The corrected GEOS2 TPW (based on Figules Ild :mal 1/ () is shown in ligure IIf. Comparing with ligure llat, we sec that the corrections have renoved the major bias in the GEOS2 TPW ficlds. We note some anount of overcoriection, especially in the Northern Henisphere subtropics. 
Docket \#-2888068

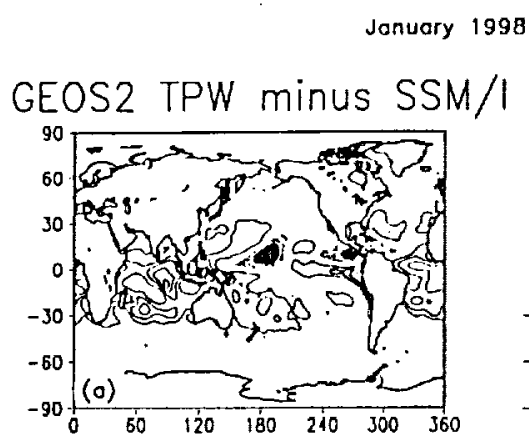

ECMWF TPW minus SSM/I
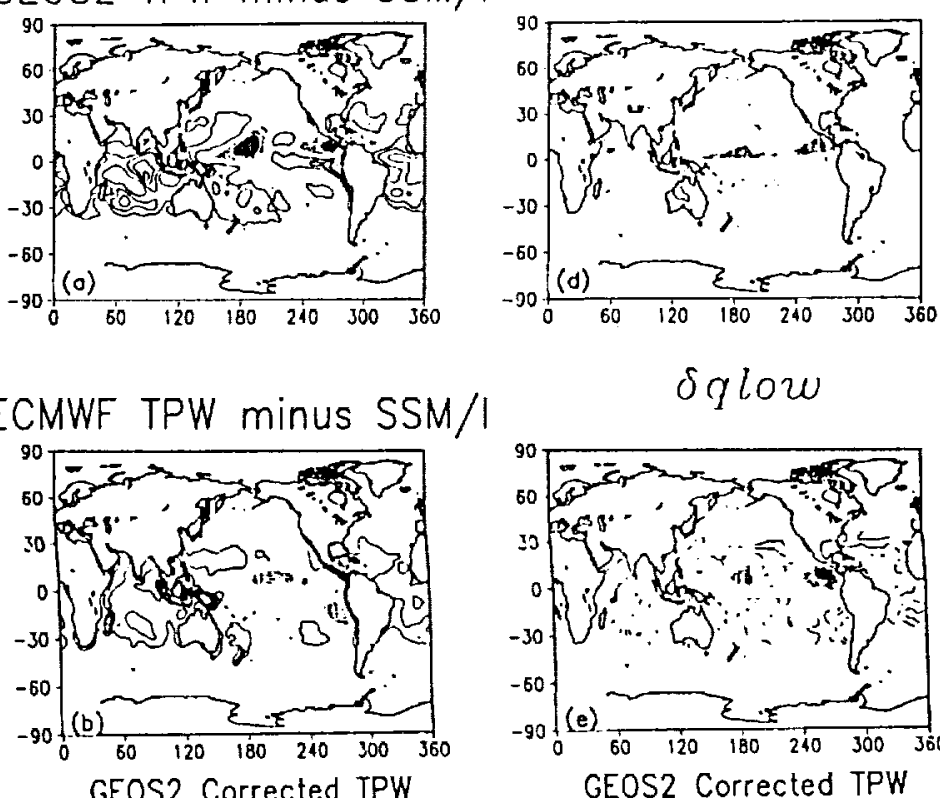

$\delta q$ low

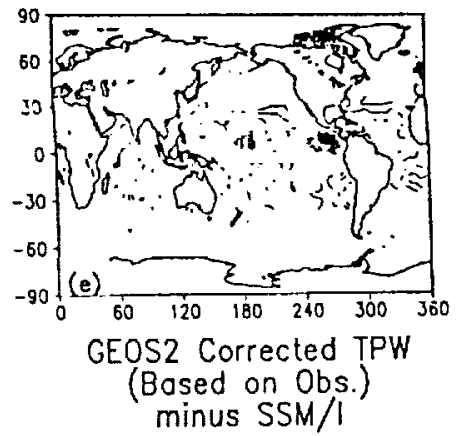

(Based on ECMWF)

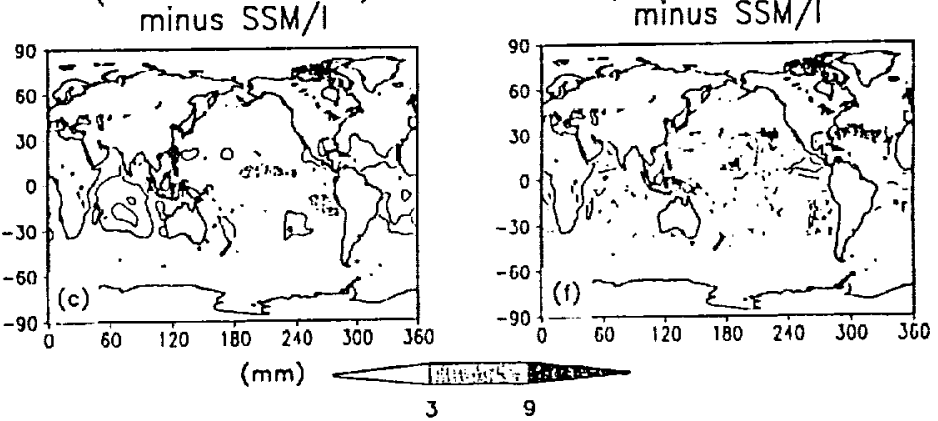

Figure 11. Diagnose of $g$ : synthetic studics of TPW differences (mm): (a) GEOS2 minus SSM/l, (b) ECMWV minus SSM/I, and (c) GEOS2 corrected TPW based an FCMIVF datt: minus SSM/I, arid satcllitcbascd TPW and layer (d) retrieved $\delta p w_{1}$ based on SCLR and $\delta R$ ad W'n from CIERES, (c) the sane as Figure 11 d except for $\delta p w_{\prime}$, and (f) GEOS2-corrected TPW based on Figures $1 / \mathrm{d}$ and $1 \mathrm{lc}$. Contour intervals are for negative values, which are opposite to the shaded values.

Finally, we diagnose $T_{a}$ for Jimuaty 1098. Since we do nol lave global ground comperature ohservations, we will agalia compare with the ECMWF analyses. Figure 12 a is the difference map of the retricved $\delta T_{g}$ minus actual (Figure 10a minus Figure (0d) bascd on the ICCMWF data. As noted previously, the global mean bias is $-0.04^{\circ} \mathrm{C}$, and stindard deviation is $1.25^{\circ} \mathrm{C}$. This again gives us confidence that our algorithm can correct the ground temperature to within those error limits. Figure $12 b$ is the mein difference in the CLR between GEOS2 and the CERES observations over the fand areas between $40^{\circ} \mathrm{S}$ and $40^{\circ} \mathrm{N}$ (the fraction of the globe covered by the CERES instrument). Differences are negative over the Sudan, Saudi Arabia, and India. Positive values occur over solutheastern Australia, southern Africa, the Andes, Central Anerica, northcrn South America, and the Tibetan highlands. Figure 12c

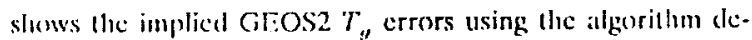
scribed alove. "lhe errors are quile large in some areats. For cxample, over the Sudan GEOS2 is more than $10^{\circ} \mathrm{C}$ teo cold, while over southeast Australia, GEOS2 is more than $12^{\circ} \mathrm{C}$ ton warm. Determining the errors in these estimates of the GEOS2 ground temperature bias will require, anong olher thi igs, refiable cstimates of the bias in the CERES measurcme: its.

\section{Discussion and Conclusions}

We have introduced a simple but quantitative metlod for relating crrors in molel-based estimates of clear-sky lo gwave fluxes (CI.R and RatlWu) to crrors in geophysical para neters. The prinuary motivation for this work is the underlying a sumption that by linking the radiation errors to crrors in tic geo- 


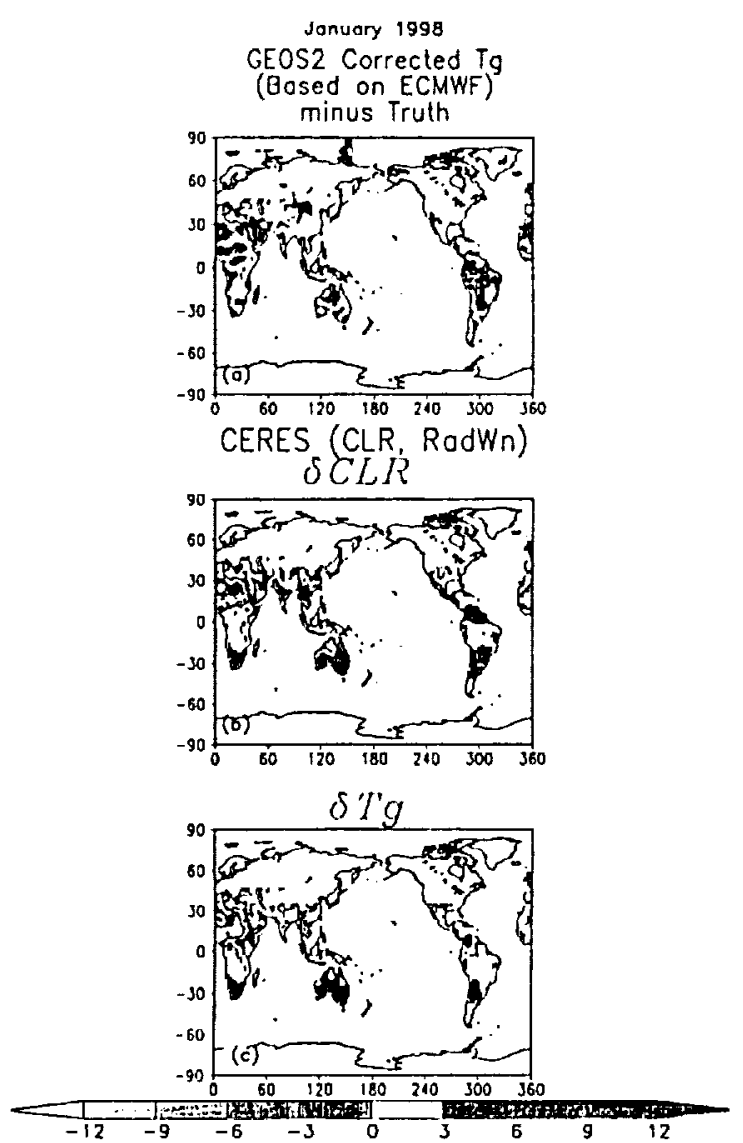

Figure 12. Diagnose of $T_{\text {: }}$ : synthetic studics of $\delta T_{,}\left({ }^{\circ} \mathrm{C}\right)$

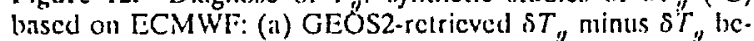
(wecn ECMWF and GEOS2. Saltellite diagnose of $\delta T_{a}$ (h) SCI.R between CERLS and GEOS2, and (c) retrieved sT, Contour intervals are for megative values, which are opposite to the shimled values.

physical parameters, we call provide greater insight to the model developer on potential model crrors. We show for a lest case (January 1998) that the method ean potentially be used to obtain quantitative cstimates of croors in ground temperature $\left(\delta T_{4}\right)$ and mosisture $(\delta p w)$ from satcllite observations. In particulir, our antlysis of syuthetic lotal and windew region clearshy llux differences (computed foum Iwo different assimilated data sets) shows that a simple lincar regression cmploying $\delta T$, and broad layer $\delta p w$ provides a good approximation to the fuil radiative transfer calculations, typically explaining more than $90 \%$ of the 6 hourly variance in the flux differences. These simple regression relations can be inverted to "retricye" the errors in the geoplysical parameters. Uncertaintics (normalized by stind ard deviationt) in the monthly me:an retricved paramclers range from $7 \%$ for $\delta T_{q}$ to about $20 \%$ for the lower tropospheric noisture $\left(\delta / w_{\ell}\right)$.

Our initial application of the methodology employed an carly CERES/TRMM ditta sct (total and window region clearsky longwave fluxes) to assess the (puility of the GEOS2 dittit. The results showed that over the tropical and subtropical uccans, GEOS2 is, in gencral, too wet in the upper tropo- splucre (mean bias of $0.99 \mathrm{~mm}$ ) and too dry in the lower troposplice (nean bias of $-4.7 \mathrm{~mm}$ ). We note tha: these errors, as well as a cold bias in the ground temperatur:, have largely been corrected in the current version of GLO:32 with the introduction of a land surface model, a moist turbulence schente and the assimilation of SSM/ total precipitalk watcr.

The methodokegy described in this paper was deyelof ed as a result of our efforts to valiclate monthly mean fields from the GİOS2 global data assimilation system, but the methodology should also prove useful for validating the climatological ficlds of globil atmospheric molels. The accuracy of the melhodology depends on the accuracy of the radiation code, surface cmissivity, the bzone profile, as well as the accuracy of the satellite estimates of total and window region clear-sky longwave fluxes. While the initial results are promising, further work is required to fully assess the sensitivity to errors. in the inpul parameters and to accoun for the mismatch between satcllite olservations and grid-scale model fields.

Acknowledpments. The anthors thank the CEIRES Instrument Team (in particular, Bruce Wiclicki, Tom Charlock, David Kralz, and Takmeng Woung) for providing early versions of the clear-sky OLR and wirrdow Mux dilta.

\section{References}

Bruhl, C., el ill., Halogen Occultation Experinent ozone chanmel val-

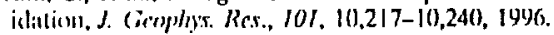

(heou, M.-1), and I. Kouvaris, Calculations of transmission functions

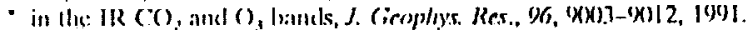

(hou, M. D., and M. Sulutz, An cificient thermal infratred rediatiom parancelerization for use in gencral circulation nodels, NASA Tech. Mome 104606 vol $3,84 \mathrm{mp} .1094$.

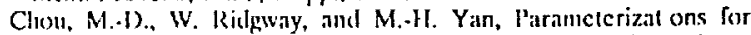
water vapor IR radiative iransfer in the niddle atmosplies $: .2$. At . mox. Sci., 52, 1159-1167, 10)5.

Cohn, E. Stephem, A. dia Silva, J. Guo, M. Sienkicwicz, and D. Lamich, Assessing the effects of tata selection with the D^O physic al-space

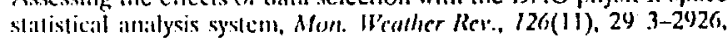
IDUS.

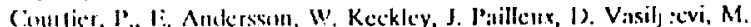

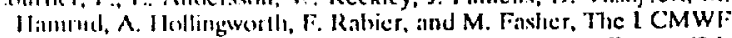
implenentation of three-dinacnsional variational assimilat on (3dVar), part I, Formulition, Q. J. R. Metcorol. Soc., 124, 171 3-1807. 1998.

Ditla Assimilation Oflice (DAO). Algorillm Theorctical Basis Docn. unem for Godddard Earth Obsenving System Data Assimilatior. System (GEOS DAS) With a Fous on Version 2, 310 pp. NASA Cioddard Sproce Flight Conl., 1906,

Draper, N. R., ;nd H. Smith, Applied Regression Anulysis, 709 pr., Johus Wilcy, New York, I logl.

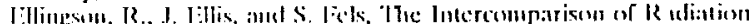

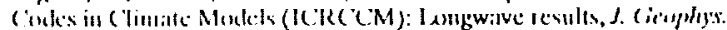
Res., $96,8924-8953,1091$.

Gates, W. L., et al., An overvicw of the results of the Ainuspheric Model Intercomparison Project (AMIP' I), Bull. Am. Mictcorol. Soc., 80. 29-55, 1909.

Helfand, II. M., A. Molod, and M. Bosilovich, Implications of a minist turbulence parameterization for the numerical prediction: of the sirmcture of the alnuspheric boundary layer, paper presented it AMS 13th Conference on Numerical Weather Prediction, Am. Meteorol. Sox., Denver. Colo.. September 13-17, 1949.

Kesier, R. I)., and M. J. Suitrez, Modeling the land surface busundary in cliniale models as a comprosite of independent vegetation stands. J. Geophlys. Res., 97, 2697-2715, 1992.

Kratz, D. P., M.-1). Chou, M. M.-1I. Yan, and C.-H. Ho, Minor trace fas radiative forcing calculations using the $k$-distrilution melhod with onc-parameter scaling. J. Geophys. Res., 10.3, 31,647-31,656, $19 \% \mathrm{~s}$.

Lill, W. K.-M., Y. C. Sud, and J.JI. Kim, lntercomparison of hydro- 
T G I

Docket \#-2:38068

1

in

WU ET AL.: ASSIESSING GROUND TTEMPERATURE AND ATMOSIVIERIC MOISTURE

logic processes in global climale molels, NASA Tecls Mrm. 10.4617 $170 \mathrm{pp}$. 1095

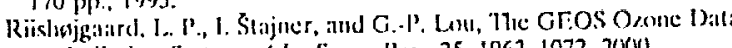
Assimilation System, Adh: Space Res., 25, 106.1-1072, 2004.

alisbury, J. W., and D. M. D'Aria, Emissivity of terrestrial matcrials, in the 8-14 micron meler atmosplueric window, Kenote Sens. Entrrin., 42, 83-106, 1992.

Schulxer, S. D., J. Praendener, and R. Rood, An issinilated datal set for Easth Science applications, Bull. dim. Atreforesl. Sic., 7.t. 23.31 $2,12,1003$.

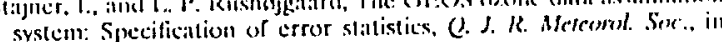
systcm: Specil

Takak, L. L. and M. J Suared, Dymanical aspects of climalc simulations using the GEOS Gencral Circulation Model, NASA Tech Memo. 104606, vol. 10, $70 \mathrm{pp} .1996$.

Wentz, F., User's Mamual, SSMMll Geophysical Tapes, $11 \mathrm{P}$., Renutc Wens. Syst., 1994. $\underset{x}{ }$ Wiclicki, B. A., B. R. Barkstrom, E. F. Harrison, R. B. Lec III, G. L.
Smill, and J. E. Coxper, Clouds and the Earth's Radiant Energy System (CERTS): An Earth Observing System Expcrinic, B, Bull. fim. Mifromol. Sic., 77, 85.7-868, 1996.

Willer, A. C.. D. I. Krat/, and S. K. Gupta, Surface cmissivity maps for use in salcilite retricvals of longwive radiation, NASA Tech.

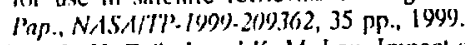

Zhom, I., Y. C. Sud, and K.-M. Lau, Inıpact of orographically induced

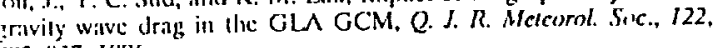
[1]. -1$) 37,19 \%$

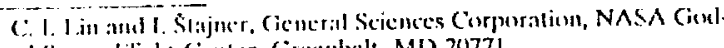

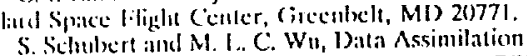

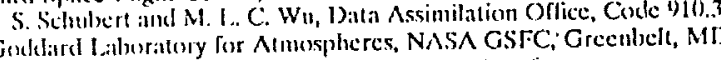
2i)771. (mwvu(irdaw. gsic.nasa.gov)

(Received December 8, IWy; revised August 2, 2000; accepled August 4, 2000.)

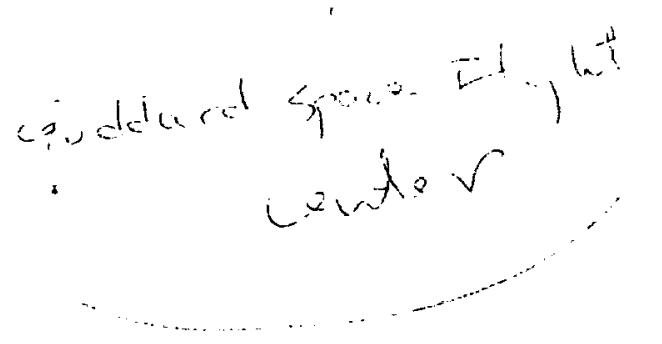

$T$ 